\section{E-LOGOS}

ELECTRONIC JOURNAL FOR PHILOSOPHY ISSN 1211-0442

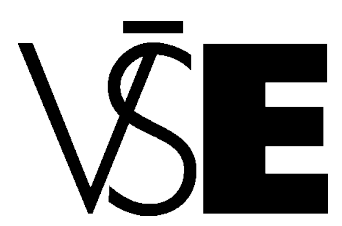

University of Economics

Prague

\title{
An Analysis of Black Heterodox
}

\section{Thought}

Jack Kerwick

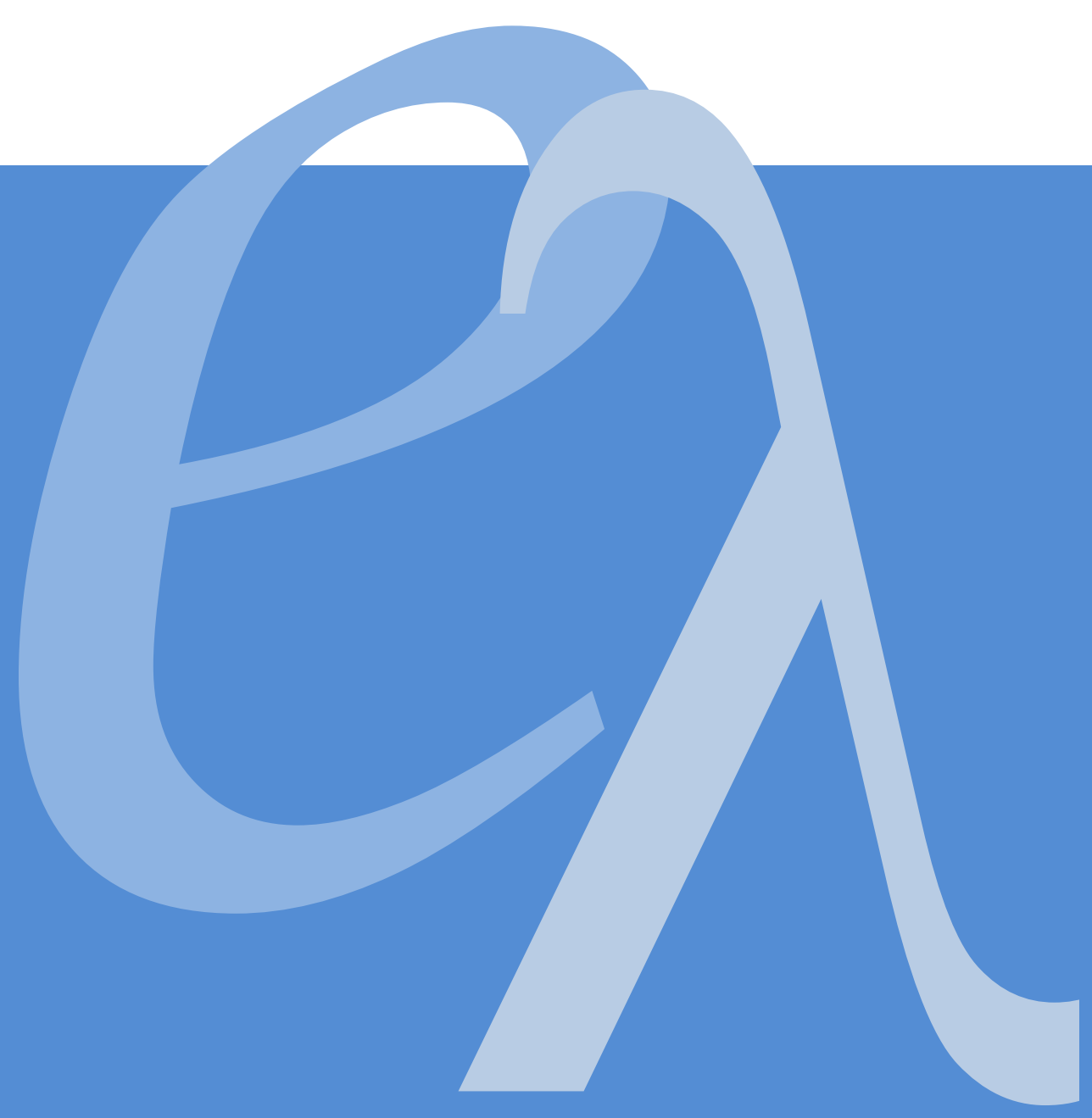




\begin{abstract}
Among the numerous currents of which contemporary American political life consists, few have been met with the curiosity that so-called "black conservatism" has succeeded in eliciting from its observers. Yet while there has been considerable talk over a so-called "black conservatism," there has been nothing like a sustained philosophical attempt to determine the character of this orientation, or whether it even is a unitary phenomenon at all. I show that while those to whom the label "black conservatism" is characteristically ascribed do indeed share in common a rejection of the conventional thinking on contemporary race-related issues, this is about all that they share, for what is commonly referred to as "black conservatism" is actually a heterogeneous assortment of distinct and, in some instances, mutually incompatible political philosophical impulses. Classical conservatism is one such impulse, but it co-exists with both libertarianism or classical liberalism and neoconservatism. In delineating each of these traditions, I focus on the thought of specific black thinkers with whom I identify them: George Schuyler and Thomas Sowell I associate with classical conservatism; Walter E. Williams I show is a classical liberal; and Alan Keyes I squarely locate within the neoconservative tradition.
\end{abstract}




\section{Introduction}

For quite some time, at least since the 1970's, there has been much chatter about the curious phenomenon designated as "black conservatism," an intellectual orientation held by a minority of black thinkers. ${ }^{1}$ In what follows, I argue that while there is indeed a "black conservatism," the orientation so-called is actually quite intellectually diverse, encompassing a multiplicity of passages of thought, conservatism being but one. In addition to classical conservatism, what is popularly known as "black conservatism" is constituted as well by strains of classical liberal or "libertarian" and neoconservative thought. ${ }^{2}$ Since that which unites those black figures associated with "black conservatism" is a shared rejection of the prevailing leftist racial orthodoxy - what we can call "black orthodoxy" - I conclude that "black conservatism" should more aptly be recognized as "black heterodoxy."

This paper is divided into four sections. In the first, I select for attention the work of George S. Schuyler and Thomas Sowell as illustrative of the "traditional" or "classical" conservatism of black heterodoxy. In the second section I highlight its classical liberal elements by examining some of the writings of Walter E. Williams, followed by the third in which I discuss its neoconservative component by analyzing the thought of Alan Keyes.

\section{Classical Conservatism}

For over two centuries, conservatives in the Anglo-American tradition, from Burke and David Hume in the eighteenth centuries to F.A. Hayek and Michael Oakeshott ${ }^{3}$ in the twentieth have unabashedly opposed the rationalism ${ }^{4}$ of their competitors. The term "rationalism" has assumed an array of meanings depending on the contexts in which it has been situated, but the rationalism with which conservative thinkers have been at odds is a peculiar conception of knowledge in terms of which human reason is assigned vast powers in scope and magnitude, a reservoir of virtually unlimited potential whose realization vitally depends upon a willingness to accept only those ideas that can be "justified" before "the bar" that it supplies. That is, the rationalist believes that knowledge must be conscious, the product of a reflective engagement susceptible to explicit excogitation in propositional terms and capable, theoretically at least, of being enlisted in the service of bringing to fruition any number of desirable purposes. From this perspective, reason is at once universal and omnipotent, the standard by which tradition, custom, and habit, the "merely" temporary, local, and transitory are to be judged.

Inseparable from this vision of knowledge is a vision of morality that, in spite of having come under fire from various quarters from the time of its emergence until the present day, continues to exert considerable influence. From this perspective, morality is comprised of principles and ideals that, by virtue of finding their 
specification in a universal reason, are themselves universal. Among such rationalistic moral doctrines are the doctrines of "individualism," "pluralism," "natural rights," "human rights," "principle of utility," "categorical imperative," and "social contract." Conservatives don't necessarily deny that, for convenience's sake if nothing else, such rationalistic language is not without its uses, and they certainly deny neither the desirability nor even the indispensability of ideals and principles to any adequate morality. In other words, it isn't principles and ideals as such that conservatives reject but, rather, the rationalist's view of them. Principles and ideals, from the conservative perspective, are abstractions constructed from the resources of a tradition of conduct-not timeless features of a trans-cultural, tradition-neutral intellect. They are the products, not the begetters, of tradition. ${ }^{5}$

The French revolutionaries and their philosophes advanced "the Rights of Man," the archetypical rationalistic moral ideology. It was against this doctrine that Burke railed and in response to which he formulated what would come to be recognized as "modern conservatism." While he not only didn't deny, but actually affirmed natural rights, Burke essentially insisted that their invocation had no place in political society given that "the objects of society are of the greatest possible complexity," a "gross and complicated mass of human passions and concerns." The natural rights to which his rivals incessantly appeal Burke derisively refers to as "metaphysic rights" and "pretended rights," "extremes" that, "in proportion as they are metaphysically true," are "morally and politically false." 6 The only rights allusions to which are appropriate in connection to civil society are culturally constituted. Burke describes them in terms of our "inheritance," an "image of a relation of blood" that has the twofold advantage of bolstering "the fallible and feeble contrivances of our reason" by assimilating "the Constitution of our country with our dearest domestic ties," as well as furnishing "a sure principle of conservation," "a sure principle of transmission," and "a principle of improvement."7

David Hume too mocked the notion that there are "moral relations, discovered by reason, in the same manner as we discover by reason the truths of geometry or algebra." 8 Moral knowledge is not derivable from "a chain of argument and induction," "metaphysical reasonings," or "deductions from the most abstract principles of the understanding." On the contrary, that which is "honorable," "fair," "becoming," "noble," and "generous," appeals not to the intellect but, rather, "takes possession of the heart, and animates us to embrace and maintain it." 9 While Burke set his sights on the rationalistic doctrine of "the Rights of Man," Hume relentlessly subjected for interrogation the characteristically rationalist idea that the legitimacy of government must be rooted in consensual foundations. This "social contract" theory Hume derides as a fiction, insisting that it is by way of habit or custom that government achieves its authority. "Obedience or subjection becomes so familiar, 
that most men never make any enquiry about its origins or cause, more than the principle of gravity, resistance, or the most universal laws of nature."10

The rationalist's ideal conception of a reason unencumbered by such parochial constraints as those imposed by the likes of tradition, custom, and habit, in conjunction with the principles/ideals-oriented universalistic vision of morality with which it is indissolubly linked, inform his or her conception of the State. The State, the rationalist holds, derives its justification from the extent to which it succeeds in realizing some ideal or set of ideals accessible to reason and believed to exist in advance of its activities: Freedom, Equality, Prosperity, Justice, Happiness, and Security are alike ideals toward the implementation of which the rationalist holds it is the duty of the State to deploy its resources. This explains the rationalist's proclivity for utopian schemes.

Conservatism, in glaring contrast, being acutely aware of the limitations of the individual's reason and the communal-i.e., local-character of morality, is staunchly anti-utopian. Ideals are abbreviations of a tradition of conduct that is itself largely unreflectively engaged in by those whose tradition it is. That it is to a significant extent uncritically partaken of is what in large measure insures its vitality and perpetuation. Yet once the provisional abridgments of a tradition are mistaken for self-subsistent ends to which the tradition itself is subordinate and in the service of which all of society's activities are to be enlisted, then the individuality and plurality that the conservative cherishes and which depend on communal tradition are imperiled. Utopian promises, thus, can't be anything other than illusory, for all such efforts to fulfill them must necessarily culminate in the impairment of precisely that which makes social life possible: tradition.

\section{George S. Schuyler}

George Schuyler was quite possibly among the greatest editorialists that America ever produced. Born in 1895 in Rhode Island, Schuyler lived in Syracuse, New York with his family until he was old enough to enlist in the United States Army. Upon the completion of World War I, he returned to civilian life, taking up residence in Harlem, where he remained until his death in 1977. It was during the decade of the 1920's when, from a thirst for intellectual stimulation rather than the appeal of its ideas, Schuyler joined the Socialist Party and began to travel within circles that would subsequently be identified with "the Harlem Renaissance." It was also during this decade that he began establishing for himself a rapidly expanding reputation as a writer. Throughout his life, in addition to authoring what has been called the first black science fiction novel, Black No More, Schuyler wrote as well for a plethora of other publications, black and white, including American Mercury, founded and edited by H.L. Mencken, the largest of literary giants of that time. Schuyler was 
a tireless champion for racial equality and a vehement opponent of communism. From 1922 until 1964, he was the editor for The Pittsburg Courier, the largest black newspaper publication in the country. In 1966, Schuyler composed his autobiography, Black and Conservative.

Although Schuyler never explicitly spoke of "rationalism," and while he, not unlike any of the black dissidents discussed in this paper, was not a professional philosopher, from his writings it is possible to extract some of the very same themes that have pervaded the literature on conservatism from Burke's day onward.

During the decade of the 1920's, when there was much talk of the "Harlem Renaissance," Schuyler mocked the notion of a distinct "Negro art." He wrote: "Negro art there has been, is, and will be among the numerous black nations of Africa; but to suggest the possibility of any such development among the ten million colored people in this republic is self-evident foolishness."11 That American blacks have produced "slave songs based on Protestant hymns and Biblical texts known as the spirituals, work songs and secular songs of sorrow and tough luck known as the blues," jazz, and "the Charleston" are undeniable facts; however, these art forms "are contributions of a caste in a certain section of the country" and, as such, "foreign to Northern Negroes, West Indian Negroes, and African Negroes." This means that they are as "expressive or characteristic of the Negro race" as "the music and dancing of the Appalachian highlanders or the Dalmatian peasantry are expressive or characteristic of the Caucasian race."

Schuyler insists that the music of American blacks, as well as the other arts upon which black artists were credited with stamping a unique impress, are, ultimately, Eurocentric. As he put the matter, "the Aframerican is merely a lampblacked Anglo-Saxon." Schuyler writes:

The dean of the Aframerican literati is W.E.B. Du Bois, a product of Harvard and German universities; the foremost Aframerican sculptor is Meta Warwick Fuller, a graduate of leading American art schools and former student of Rodin; while the most noted Aframerican painter, Henry Ossawa Tanner, is dean of painters in Paris and has been decorated by the French Government. 12

Schuyler notes that none of this should be of any surprise considering that "the Aframerican is subject to the same economic and social forces that mold the actions and thoughts of the white Americans." He continues:

In the homes of the black and white Americans of the same cultural and economic level one finds similar furniture, literature, and conversation. How, then, can the black American be expected to produce art and literature dissimilar to that of the white American? ${ }^{13}$ 
I submit that throughout this essay - one written very early on his careerSchuyler exhibits an acute, characteristically conservative sensitivity to the indispensable role that culture or tradition plays in shaping and even constituting the individuality, the intellectual horizons, of those who can claim it as their own, a sensitivity that would pervade his thought throughout the remainder of his life. Radical individualism, the notion that anyone can transcend the habits, dispositions, mores, and traditions of the society from within which he or she was nurtured, is a species of rationalism, and although those on whom Schuyler sets his sights make no such assertions on the part of the individual as such but, rather, the race to which individuals belong, claims on behalf of "self-made" racial groups shedding the cultural contexts within which they developed are no less fantastic and no less rationalistic then tales of "self-made" individuals recreating themselves de novo.

Four decades later, Schuyler continued to stress the inexorability of culture in determining the self-understanding, whether severally or collectively, of American blacks. The variety of "Back to Africa" movements that have proliferated since the days of the American Colonization of Society have all failed, Schuyler explains, because, again, "the American Negro" has vastly more in common with his white brethren in the United States than he shares with non-Americans of the same or darker skin pigmentation. Although "their training and education would undoubtedly be helpful to the backward and newly-emergent states" throughout the Third World, "barriers of language and culture" insure that black Americans "in large numbers would not be accepted today anywhere on earth....."14 As for their acceptance in Africa, Schuler writes:

Soil depletion, desiccation and the general impoverishment and ignorance of quarreling ethnic groups indigenous to the Dark Continent make it most unappealing to people whose standard of living is in general superior to that of Europeans, to say nothing of Africans.

"American Negroes" have "nothing whatever in common with even the most advanced Africans....."15

This keen understanding of and deep appreciation for the tradition-constituted character of knowledge, individuality, and morality finds direct expression in Schuyler's argument against what would come to be known as the Civil Rights Act of 1964. It is his subscription to this classically conservative vision that both informs and reflects as well his attitude toward politics, specifically, the sort of change that is both possible and desirable for government to try to affect. His position on change also squarely locates Schuyler clearly within the classical conservative tradition.

Schuyler invokes several considerations against the Civil Rights Bill, but the essence of his position is that it is of a piece "of largely unenforceable legislation" that "has everywhere been characteristic of political immaturity." This "political immaturity" is almost invariably coupled with "a passion for novelty" that inspires 
in the country that it inflicts a propensity "to speed social change by law," a disposition that in turn is rooted in the assumption that "it is possible to make people better by force." Yet this supposition and the willingness to act on it have "been the cause of much misery and injustice throughout the ages." A country like America is especially prone to be seized by this "passion for novelty," for it is a "young nation" that "grew out of conquest, immigration, revolution and civil war...." 16 Notice, Schuyler is under no illusion that America is unique among the nations of the world in allegedly having been founded, all at once, as it were, on an "idea," "ideal," or "proposition," for he was well aware of the fact that it owes its origins to the very same sorts of "accidents" of history by which every other country emerged.

If they are to be durable and beneficial, changes in race relations, like all social changes, cannot be abruptly designed by legislators availing themselves of the State's apparatus of power but, instead, transpire gradually in accordance with the habits and sensibilities of the majority of its citizens. Change, in other words, must be orderly if the ostensible ends of the legislation proposed are to escape being undermined. Schuyler succinctly states: "It is axiomatic that it takes lots of time to change social mores, especially with regard to such hardy perennials as religion, race and nationality, to say nothing of social classes." 17 Insofar as legislation fails to accommodate the habits and customs of those to whom it pertains, "the more difficult and expensive" will its enforcement be, and "the less popular," the less legitimate, will the government become.

Schuyler spent his life addressing the treatment to which American blacks had been subjected by their fellow Americans, and even while arguing against passage of the proposed Civil Rights Bill, he makes unmistakable his contempt for the oppression under which blacks had been made to labor. The majority's attitude toward black Americans "is morally wrong, nonsensical, unfair, un-Christian and cruelly unjust...." However, while "changes have been very slow since 1865" when blacks were finally emancipated from slavery, what changes have occurred "have been marked," and "civil rights laws, state or federal, have had little to do with it." These civil rights laws "have been enforced and accepted only when the dominant majority acquiesced, and have generally lain dormant in the law books." That is, "custom has dictated the pace of compliance."18

Schuyler's "principal case" against this Civil Rights bill is anchored in his affirmation of liberty. But the liberty to which he appeals is not an abstraction, a trans-cultural, trans-historical, timeless Right or Ideal, but the concrete institutional arrangements of American society, specifically its federalist constitutional framework and the wide dispersal of power of which it consists.

The principal case against a federal Civil Rights law is the dangerous purpose it may serve. It is still another encroachment by the central government on the federalized structure of our 
society... Under such a law the individual everywhere is told what he must do and what he cannot do, regardless of the laws and ordinances of his state or community. This is a blow at the very basis of American society which is founded on state sovereignty and individual liberty and preference. ${ }^{19}$

That is, it is the liberty implied in our constitution, not the liberty expressly proclaimed in the Declaration of Independence, that Schuyler invokes.

In his autobiography, Schuyler corrects the rationalistic tendency on the part of his opponents to judge America in the light of an ideal of justice; instead, he remarks, all judgments must be in terms, not of unrealized possibilities, but actual realities. The insistence that in politics the focus be on the concrete and actual rather than the abstract and ideal is a hallmark of conservative thought that we might describe as its vehement anti-utopianism. Among the multiracial nations of the Earth, contrary to her critics, America is "dealing better" with its racial challenges than any other. Schuyler asserts that while "it was all well and good to expect more of America than any other country," it must be remembered that what "was an American problem was also a global one from which no country was free." In fact, "it is in a way indicative of the superior position of the Negro in America that he has such rising expectations, elsewhere chiefly non-existent, save among a tiny minority of the better circumstanced." 20

In summation, Schuyler's thought is representative of classical conservatism, for like his predecessors stretching back to Burke, he argued against the rationalistic doctrines of his liberal, socialist, and communist rivals by invoking tradition and culturally-centered conceptions of knowledge, morality, and politics. The expanse of the individual's intellectual horizons and moral potentialities, Schuyler asserted, like the possibilities that exist for societies, far from being determined by eternal principles or ideals that are alleged to subsist in advance of social practices, are in reality the latter's products. Thus, political or social change, whether it is change in race relations or any other kind, cannot be achieved unless it is intimated by and, hence, readily incorporated in, tradition.

\section{Thomas Sowell}

Thomas Sowell is by trade an economist whose area of specialization is the history of economic thought. Born in Charlotte, North Carolina in June of 1930, he moved to Harlem with extended family members when he was nine. Upon quitting high school, Sowell left home and joined the army where he subsequently acquired an interest in photography. When returning to civilian life, he decided to pursue a higher education, first at Howard University, and then at Harvard, where he graduated with honors. Sowell decided to pursue graduate studies and in the late 1960 's he was awarded a doctoral degree in economics from the University of 
Chicago. Throughout his career, he has authored over 30 books and numerous journal articles, and for over the last 20 years he has been a nationally syndicated columnist. Although he is an economist by profession, Sowell has written extensively with respect to all manner of issues - especially race, an area on which he has brought his knowledge of economics to bear. ${ }^{21}$

Sowell has spent most of his professional life exposing the follies of rationalism, as they pertain both to issues that are racially oriented as well as those that are not obviously so, yet it his seminal Knowledge and Decisions that is a tour-deforce against this "treacherous" intellectual disposition. ${ }^{22}$ Rationalism "accepts only what can 'justify' itself to 'reason' - with reason being narrowly conceived to mean articulated specifics." But the "highly rational intellectual 'models' of human behavior" that comprise rationalism "suffer from an air of unreality," a fact that is readily witnessed as soon as the "hypothetical, computer-like incremental adjustments by coolly calculating decision makers" on which they rely "are compared to the flesh-and-blood reality of decision by inertia, whim, panic, or rule of thumb." 23

Rationalism admits of a multiplicity of variations but all versions are guilty of committing what Sowell describes as "the animistic fallacy," the belief that all instances of order are "the result of purposeful activity toward the goal achieved...." The animistic fallacy has an extensive and storied past, having made appearances in a wide variety of human disciplines. This should come as no surprise, for "perhaps the simplest and most psychologically satisfying explanation of any observed phenomenon is that it happened that way because someone wanted it to happen that way." 24 Sowell states that generally speaking, the rationalistic terms in which intergroup disparities are explained lead to the animistic fallacy, for whether they invoke such notions as "ability," "merit," or "discrimination," cultural considerations are equally excluded. "Ability" or 'discrimination' are thus among the first explanations seized upon" to account for these inequalities, "much as primitive man explained the rustling of leaves by someone's deliberate moving of them." However,

once it is clear that results observable at a given point in time may be part of a process that stretches far back in time, it is no longer automatically necessary that their current situations be a result of either meritorious or unworthy actions by contemporaries-either group members or others.

Sowell concludes: "Differences in cultural values, for example, have deep roots in centuries past and profound impact on current behavior." 25

Culture, according to Sowell, far from being the product of deliberate design, is "an evolutionary product," by which he means "an ecology of human relations" that has been centuries and even millennia in the making. From this anti-rationalistic perspective-Sowell calls it "evolutionism" - "it is by no means clear that any and all 
well-articulated reasons for changing particular parts of this social ecology must be valid." The problem is that "articulated rationality can seldom predict very far or very specifically," and so "a policy's unintended consequences throughout a complex system is a weighty consideration." 26 It is of vital importance that our cultural traditions not be undermined, for "culture provides a wide range of beliefs, attitudes, preferences, and customs" 27 on which millions of human beings rely for their activities.

In The Vision the Anointed, Sowell elaborates on this understanding of cultural tradition, as well as the conception of change that it entails. While change is an inexorable fact of life, societies should proceed with great caution when attending to it, opting for changes that are small and gradual over those that are large and dramatic, for "barbarism is....an ever-present threat when the civilizing institutions are weakened or undermined." 28 Sowell frequently and approvingly alludes to Burke, whose "sense of the fragility of civilization led" the latter to "regard the promotion of social experimentation and atomistic reason as a dangerous playing with fire." 29 The problem is that the rationalist's epistemological and moral conceptions - "the notion that 'society' must justify itself before the bar of 'reason'" implies "that there is some individual or group capable of such encyclopedic knowledge" 30 as to supply "solutions" to all of society's problems. This is the rationalist's dream.

Given his anti-utopianism, Sowell unabashedly declares that "there are no 'solutions'....only trade-offs," a fact of the human condition that promises that "many desires" will remain "unfulfilled" and there will continue to be "much unhappiness in the world." The twofold challenge posed to us is "how to make the best trade-offs from the limited options available," and how to achieve the "realization that 'unmet needs' will necessarily remain," for "attempting to fully meet these needs seriatim only deprives other people of other things, so that a society pursuing such a policy is like a dog chasing its tail." Thus, "particular solutions to particular problems are far less important than having and maintaining the right processes for making trade-offs and correcting inevitable mistakes." 31

Sowell's tradition-based vision of reason, knowledge, morality, and politics establishes, I have argued, that like Schuyler before him, he is a conservative in the tradition of Burke.

\section{Classical Liberalism}

The name "classical liberalism" has today been largely replaced by "libertarianism." Doubtless this is in no small part because "liberalism" has come to be associated with a political-moral ideology that, in spirit if not in every detail, bears few if any similarities to that to which the term historically referred. Regardless of 
this alteration in nomenclature, and irrespective of the reasons that account for it, I will here continue to refer to this political philosophical vision by its original name.

Though in the seventeenth and eighteenth centuries, when it originated, classical liberalism had its share of eloquent exponents, the British philosopher John Locke provided what would become widely recognized as among its most distinguished defenses. If Burke is classical conservatism's "patron saint," then Locke is classical liberalism's.

According to Locke, the State or government must be rooted in contractual foundations. More specifically, only if the government has the consent of the governed can it claim legitimacy. Locke invoked a device common to social contract theorists of his time, namely, "the state of nature," a pre-political condition in which individuals have both "perfect freedom to order their actions and dispose of their possessions and persons," as well as "equality, wherein all the power and jurisdiction is reciprocal, no one having more than another." 32 Because this "state of nature" has its share of limitations, human beings eventually abandon it and, from enlightened self-interest, agree to form political society. But this transition doesn't alter their realization that by nature they are and always will be "free and equal," for it is "reason" that "teaches all mankind, who will but consult it, that being all equal and independent, no one ought to harm another in his life, health, liberty, or possessions," 33 goods to which all human beings have divinely endowed rights that Jefferson would later describe as "unalienable." And since, Locke states, all persons are "by nature all free, equal, and independent, no one can be put out of this estate, and subjected to the political power of another, without his own consent." 34

The stark differences between the classical conservative vision and Lockean-style classical liberalism must not go unnoticed. The latter's atavistic conceptions of reason and individuality, abstract and timeless understanding of "natural rights," and ahistorical account of the origins and legitimacy of government, reveals it as a variety of precisely that orientation with respect to which classical conservatism has always been the antithesis: rationalism. This point must be made not in order to determine the one perspective intellectually superior to the other, but so that the philosophical diversity among the black heterodox may be brought to light.

\section{Walter E. Williams}

Walter E. Williams was born in Philadelphia, Pennsylvania in 1936. While a toddler, his father abandoned his mother, leaving her to raise Walter and his sister in the Richard Allen Homes Housing Project. In the late 1950's, Williams was drafted into military service. Upon being discharged, he pursued collegiate studies, and in the 1970's he earned his doctoral degree in economics from the University of California at Los Angeles. Williams is an economics professor at George Mason 
University, the author of several books and numerous journal articles, and a nationally syndicated columnist.

In his Do the Right Thing, a collection of his columns, Williams unambiguously explains his "values system."

At the root of my values system is the principle of natural law as expounded by philosophers like John Locke and William Blackstone and adopted by early American notables such as Thomas Jefferson, James Madison, George Mason, Patrick Henry, and Thomas Paine, among others, and captured so simply, elegantly, and compellingly in our Declaration of Independence in the phrase "We hold these truths to be self-evident, that all men are created equal, that they are endowed by their Creator with certain unalienable rights, that among these are Life, Liberty and the Pursuit of Happiness." 35

Notice, Williams considers himself a proponent of natural law, but this is not the natural law of such pre-modern, classical and medieval thinkers as Augustine and Aquinas, but the peculiarly modernistic construal of natural law characteristic of such rationalistic thinkers as Locke, Jefferson, Patrick Henry, and Thomas Paine. That is, unlike Sowell, for instance, with whose thought his is usually identified, Williams draws philosophical inspiration from a tradition of thinkers whose cast of mind classical conservatives of a Burkean persuasion have always fiercely resisted.

Locke's impress upon Williams' exposition of natural law is unmistakable. "The first principle of natural law," he states, "holds that each person owns himself." Self-ownership follows from the fact that "in the state of nature, without government, all people are free and equal but insecure." The insecurity that is our condition in the state of nature owes to the fact "that other people may not respect our self-ownership rights and, through intimidation, threats, and coercion, wrongly confiscate our property and violate our persons." Due to this precarious situation, people leave the state of nature and "form governments granting them certain limited powers."

Since, though, by nature we are (equally) free and equal, "we all have the right to protect ourselves, family, and property from encroachment by others." So, "when our rights to life, liberty, and property are violated, we have the right to be prosecutor, judge, jury, and, if need be, executioner." Thus, to the governments that we form "we grant these rights...in exchange for the guarantee that the state will perform these security functions." In other words: "We give up only the rights necessary for government to perform its only function - protecting our security." 36

Williams charges fellow Americans with abandoning "those basic ideals and principles on which our prosperous nation was built" -ideals, for example, like Freedom - for the sake of "other ideals, such as equality of income, sex and race balance, orderly markets, consumer protection, energy conservation, and environmentalism, just to name a few...."37 However, in order to achieve these latter 
goals government must "confiscate...through intimidation, threats, and coercion," the resources of some citizens so as to redistribute them to others. Yet if such methods "are clearly an affront to human rights when done privately," then they are no less a violation of human rights when appropriated by a collectivity - even if that collectivity is the government acting by "legal sanctions" or on behalf of "the majority." 38

Americans must ask whether an act clearly immoral and criminal when done privately becomes moral when done collectively and given legal sanction. The unambiguous answer will be that legality is a poor guide to morality. After all, slavery and apartheid were legal, as were the Nazi persecution of Jews and the Stalinist and Maoist purges. But the fact of being legal did not make them moral acts. ${ }^{39}$

"Immoral laws," Williams bluntly asserts, "aren't worthy of obedience." 40

Among those immoral laws that Williams believes demand disobedience are those criminalizing "vices." He writes: "For the government to declare a vice a crime is to violate those natural law guarantees of life, liberty, and pursuit of happiness, which are enunciated in our Declaration of Independence." 41 Since no individual has "the right" to punish others for their vices, government must lack this right, for whatever rights government possesses it derives from its citizens. Williams laments that "these principles of natural law that played such an important role in the framers' thinking about our Constitution are held in high contempt by Congress, the courts, and...most Americans." He is especially troubled by the fact "that black Americans share so much of this generalized contempt and eagerly advocate and participate in the attack against the principles of natural law," for "blacks, more than any other Americans, should love and respect natural law and have the deepest suspicions of government," particularly a government that was guilty of perpetrating "the abuses of Reconstruction and Jim Crow" that "were rooted in disrespect for natural law." 42

Williams, I have shown, is not a conservative, but a classical liberal of a Lockean sort. He articulates his political-moral vision in the same rationalistic idiom within which his welfare-state liberal and socialist opponents frame theirs. Both Williams and his adversaries construe morality primarily in terms of "principles" and "ideals," ostensibly trans-cultural goals upon which human societies are "founded" and in the service of which they must be enlisted. Williams invokes "natural law," a purportedly universal code of morality comprised of self-evident and abstract propositions - "Rights"; "the state of nature," a condition of relatively peaceful co-existence between individual persons prior to the formation of political or civil society; and a contractually-based notion of the State according to which only those governments that have elicited the consent of its citizens and safeguard their 
"inalienable rights to life, liberty, property, and the pursuit of happiness" are legitimate and, thus, deserving of obedience.

\section{Neoconservatism}

There is a third type of black heterodoxy that is neither classically conservative nor classically liberal. For lack of a better term, I will call it neoconservatism. Since relative to the classical conservative and liberal traditions neoconservatism is a relatively new political philosophical orientation, the scholarly literature concerning it is comparatively scarce. ${ }^{43}$ Furthermore, neoconservatism is typically identified as a popular political movement, not a philosophical or intellectual tradition. That is, it is usually recognizable in terms of the substance or content of the positions to which its adherents subscribe on contemporary issues of policy. Still, from those positions it is far from impossible to abstract certain mutually (even if not systematically) related formal considerations upon which they are rooted, considerations largely shared by the classical liberalism of which Williams is an exponent and which, thus, expose neoconservatism as another species of rationalism.

Leo Strauss is typically recognized as the chief, or at least original, inspiration of what has subsequently been called neoconservatism. Strauss defends against its "historicist" objectors - by which he means Burke and the conservative thinkers who followed in his wake - a conception of "natural right" that he claims has roots stretching back to the classical era. He writes that "the need for natural right is as evident today as it has been for centuries and even millennia," for "to reject natural right is tantamount to saying that all right is positive, and this means that what is right is determined exclusively by the legislators and the courts of the various countries." 44 According to Strauss, Burke and "the historical school" that the former credits the latter with pioneering were aware of the "necessarily...revolutionary, disturbing, unsettling effect" of the widely held belief in natural rights. Things couldn't be otherwise, for "the recognition of universal principles forces man to judge the established order, or what is actual here and now, in the light of the natural or rational order," an order of which "what is actual here and now is more likely than not to fall short...." 45 Strauss writes:

The recognition of universal principles thus tends to prevent men from wholeheartedly identifying themselves with, or accepting, the social order that fate has allotted to them. It tends to alienate them from their place on the earth. It tends to make them strangers, and even strangers on the earth. 46

For neoconservatives, only "liberal democracies" can insure the protection of "human rights," and the United States is the liberal democracy par excellence. For this reason, Francis Fukuyama asserts that "the United States needs to remain engaged in international affairs," for "American power has been and could be used for moral 
purposes...."47 Allan Bloom, usually credited with being among neoconservatism's principal architects, writes that since "modern philosophy" has established that "political equality" is "the only just system of society," it follows that "there is no intellectual ground remaining for any regime other than democracy." 48 That the United States has a special duty to promote "liberal democracy" should be of no offense to any rational being, least of all those who had no objections to America' involvement in the second World War, for World War II, Bloom believes, "was really an educational project undertaken to force those who did not accept" American "principles of freedom and equality and the rights based on them" to do so. There can be no legitimate reason for not accepting these principles, for they "are rational and everywhere applicable." 49

On its face, neoconservatism appears not all that different from classical liberalism: both presuppose an abstract, universalistic conception of human reason; a trans-cultural, tradition-neutral, principles and/or ideals-based vision of morality; and a global, ideals-driven conception of politics. Yet there are indeed differences between the two, in terms of both the principles and themes emphasized as well as the conclusions regarding policy issues drawn from those principles. Classical liberals like Williams, as we have seen, argue from principles of natural right to an unambiguously decentralized system of American government that exists to insure a maximal degree of liberty for its citizens. Neoconservatives, while claiming to favor this same kind of liberty, reason that these principles, being timeless and universal, deserve protection by the government not just at home but abroad. This, at any rate, is one key difference between these two perspectives.

\section{Alan Keyes}

Admittedly, Keyes doesn't squarely fit into the neoconservative mold. He staunchly rejects the materialistic, secular, socialistic impulses of the dominant ideology of welfare-state liberalism, and unlike classical conservatives, he seems to hold that the State is entrusted with the responsibility of promoting moral truth, as opposed to peaceful co-existence between citizens holding a diversity of disparate conceptions of moral truth. Furthermore, Keyes is no classical liberal, for while he affirms the same "inalienable rights" to life, liberty, property, and the pursuit of happiness as the typical classical liberal, he is significantly more likely than the latter to favor substantial governmental intervention, both domestically and internationally, to promote those rights. Due to these considerations, I contend that it is not with injustice that we associate Keyes with neoconservatism.

The one issue to which Keyes repeatedly speaks is the issue of abortion, of which he is an unequivocal opponent. The immorality of abortion is a recurring theme throughout his essays, and while it seems to occupy a disproportionate 
amount of space, Keyes explains that his focus on abortion owes not just to the gravity of the issue in itself, but "the corruption of our idea of freedom" of which it is emblematic, "a corruption that is really killing us."

If we harden our hearts against our offspring, and if we aggrandize our self-fulfillment to the extent that we are even willing to kill our offspring, that is the extreme case of the selfcentered and egotistical and self-worshipping concept of freedom I think is being promoted in various ways in the society.

Abortion is illustrative of that debased notion of freedom according to which there is "the right to destroy the rights of others." 50 Thus, for Keyes, there are but two options of which we can avail ourselves. "We are going to have to decide whether we shall quote the words of the Declaration of Independence with real conviction" and "stand by the great principle that declares that all human beings are 'created equal' and 'endowed by their Creator' with 'the right to life,"' or "whether we shall take that document and throw it on the ash heap of history...." 51

Freedom entails "moral requirements" that are specified in the Declaration of Independence, a document that affirms unambiguously that "our freedom comes from a transcendent authority - from the Creator." 52 Keyes asserts that "the real crisis of our times is... a crisis of character," a crisis engendered "by our inability to admit the moral requirement of freedom," "our insistence on marginalizing Truth." 53 But if we are determined to reject "the idea that there is a foundation in our lives for human justice and the observance of human justice," a Supreme "Source of unalienable rights and the Policeman stationed in every human heart" on the basis of which "the great American experiment in liberty" and the "relatively universal" "moral regime" that it "involved" developed, then it will be at nothing less than the cost of that experiment, the loss of America as we have always known it. ${ }^{54}$

Keyes underscores the Declaration of Independence's affirmation of their divine ground, it is true, but the moral vernacular of rationally self-evident "principles" and "unalienable human rights" in which he speaks reveals his distance from the conservatism with which Keyes is popularly associated. The classical conservative tradition, as we have seen, is decidedly anti-rationalistic, yet the political philosophical orientation to which Keyes subscribes, what I have here identified as neoconservatism, is an expression of rationalism.

While an ambassador to the United Nations, Keyes explains that he often had to engage in the "not too terribly easy" enterprise of defending his position in favor of strong American-Israeli relations, a task the challenges of which arose from the transitory character of the "practical, pragmatic," and "entirely material" considerations in terms of which such defenses were not infrequently made by others. After all, since "the world has an unwieldy way of changing," it is conceivable that "there might even be compelling geo-strategic reasons why we 
should actually abandon" the U.S.-Israeli alliance. Yet at "the level of our moral identity," Keyes continues, there is no difficulty at all in justifying America's particularly close relationship with Israel. And what is true of America's connection with Israel can equally be said on behalf of all of the close relationships that she has fostered throughout her history. "When we really get down to it...and we come face to face with the ultimate issues of war and peace," regardless of the countries under discussion, "all of those geo-strategic things go by the boards," a fact amply supported by just a cursory reading of previous presidents' speeches. Such speeches invariably contain "arguments that stir the moral sentiments of this nation, and that call upon our willingness to moral commitments, to the things that we believe are right. 55

Keyes adds a cautionary note, reminding us that appeals to "moral identity" in supporting America's involvement with other countries presupposes that there is "an understanding of our common moral ground." What is this "common moral ground?"

We must be clear on this: the moral principles that this nation stands on, are not principles lost in the mists of time. They're not things we are making up as we go along. In fact, we know what they are. They were clearly articulated when the nation was founded. They have been at various reprises in our history hallowed with the blood of our patriots, and called upon by those who were living without justice. And they have been used successfully to motivate our will in war and to move our conscience in times of peace, to shape this nation's institutions in light of its better principles. ${ }^{56}$

The "moral principles" on which "this nation stands" are the "self-evident" "truths" that "our Founders set down" and that "still ring down, through our history, with a grand decisiveness," namely, the principle(s) that "all men are created equal" and "endowed by their Creator with certain unalienable rights." It is these principles that, "in spite of all our human frailty and weakness" and "the whole weight of human history which was against the quest for real justice," nevertheless "we have managed decade by decade through these two centuries and more of our existence to move in the direction of greater and greater respect for justice, liberty, and right." It is these principles that comprise "everything we are," for "everything we claim to be as a free people is summarized in" them. ${ }^{57}$ Our "guiding principles" are "our essential selves," so if we "disregard" them "at home," they will "lose credibility and we would lose our will in the struggle to defend them around the world." 58 It is these principles embodied in the Declaration that "give content to our valiant fight for the rest of humankind...." 59

Keyes exemplifies neoconservative thought. Not unlike his non-black counterparts, he embraces an unencumbered account of reason and a vision of morality no less universalistic and abstract, an ideology of "principles," specifically, 
inalienable human rights, that it is the responsibility of the American government to ambitiously promote not only at home but globally.

\section{Conclusion}

My objective in this essay was to show that the conventional wisdom notwithstanding, "black conservatism" is a misnomer when it is used to identify the political philosophical orientation of a relatively small, but significant, minority of black thinkers who resolutely reject the left-leaning, political orthodoxy of the majority of their brethren, for beyond a contemptuous attitude toward that orthodoxy, they share little else. Hence, I submit that "black heterodoxy" would be a more appropriate nomenclature. Also, I identified at least three currents of thought within black heterodoxy, classical conservatism, classical liberalism, and neoconservatism, and selected representative thinkers of each. George Schuyler and Thomas Sowell I linked with classical conservatism, Walter Williams with classical liberalism, and Alan Keyes with neoconservatism. 


\section{End Notes}

1. Authors Joseph Conti, Stan Faryna, and Brad Stetson are among those who have contributed in no small measure to the notion that all blacks who repudiate the prevailing racial orthodoxy are adherents of "black conservatism." See their Black and Right: The Bold New Voice of Black Conservatism in America (Westport, Connecticut: Praeger, 1997). Also, consult Conti and Stetson's, Challenging the Civil Rights Establishment: Profiles of a New Black Vanguard (Westport, Connecticut: Praeger, 1993). The former is a study of black rightists like Jesse Lee Peterson, Larry Elder, and Deroy Murdock who are by and large public figures accustomed to addressing popular audiences. The latter text, in contrast, exposits and analyzes the thought of such scholarly figures as Thomas Sowell, Shelby Steele, Glenn Loury, and Robert L. Woodson.

2. A few remarks are in order. First, the provisional character of this threefold distinction between classical conservatism, classical liberalism, and neoconservatism should be duly noted from the outset. It should also be observed, however, that its value is rooted chiefly in this fact, for its openendedness supplies a scheme or outline within which significant philosophical differences between thinkers typically linked together can be clearly delineated. Finally, while I am confident that I submit persuasive reasons for making the associations that I do between individual thinkers and political philosophical traditions, it must be admitted that my selections are not without some degree of arbitrariness. For this, though, I implore the reader to be merciful, for such arbitrariness I have tried to minimize and, besides, given the nature of the study, it is inescapable.

3. Jerry Z. Muller's, Conservatism: An Anthology of Social and Political Thought from David Hume to the Present (Princeton: Princeton University Press, 1997) is an excellent survey of this 200 year intellectual tradition in which the reader is provided access to the work of the aforementioned thinkers.

4. The disposition that I here refer to as "Rationalism" has alternatively been described by some of its opponents as "constructivism"(F.A.Hayek) and "gnosticism" (Eric Voeglin). See Hayeks, Law, Legislation and Liberty. 3 vols. (Chicago: The University of Chicago Press, 1973-1979), and Voeglin's, The New Science of Politics (Chicago: The University of Chicago Press, 1997).

5. See Michael Oakeshott's insightful discussion of the relationship between tradition and principle in the essay "Rationalism in Politics," in Rationalism In Politics and Other Essays (Indianapolis: Liberty Fund, 1962). 
6. Edmund Burke, "Reflections on the Revolution in France," in The Portable Edmund Burke. Ed. Isaac Kramnick (New York: Penguin Books, 1999), 451-452.

7. Ibid., 207.

8. David Hume, Enquiries Concerning the Principles of the Understanding and the Principles of Morality. $3^{\text {rd }}$ ed. Ed. P.H. Nidditch (Oxford: Oxford University Press, 1990), 288.

9. Ibid., 172.

10. David Hume, "Of the Original Contract," in Essays Moral, Political, and Literary. Revised ed. Ed. Eugene F. Miller (Indianapolis: Liberty Classics, 1987), 466.

11. George S. Schuyler, "Negro-Art Hokum," in Rac[e]ing To the Right. Ed. Jeffrey B. Leak (Knoxville: University of Tennessee Press, 2001), 13.

12. Ibid., 14 .

13. Ibid., 15.

14. George S. Schuyler, "The Future of the American Negro," in Rac[e]ing To the Right. Ed. Jeffrey B. Leak (Knoxville: University of Tennessee Press, 2001), 109.

15. Ibid., 110.

16. George S. Schuyler, "The Case against the Civil Rights Bill," in Rac[e]ing To the Right. Ed. Jeffrey B. Leak (Knoxville: University of Tennessee Press, 2001), 97.

17. Ibid., 97-98.

18. Ibid., 99 emphasis mine.

19. Ibid., 103.

20. George S. Schuyler. Black and Conservative: The Autobiography of George S. Schuyler (New Rochelle: Arlington House Publishers, 1966), 332. 
21. For more (auto)biographical information on Sowell, see his A Personal Odyssey (New York: Simon \& Schuster, 2000), as well as his A Man of Letters (New York: Encounter Books, 2007).

22. Thomas Sowell. Knowledge and Decisions. (New York: Basic Books, 1996), 154.

23. Ibid., 100.

24. Ibid., 97.

25. Ibid., 99.

26. Ibid., 103.

27. Ibid., 101.

28. Thomas Sowell. The Vision of the Anointed: Self-Congratulation as a Basis for Social Policy. (New York: Basic Books, 1995), 118.

29. Ibid., 119.

30. Ibid., 110.

31. Ibid., 113.

32. John Locke. Two Treatises of Government and A Letter Concerning Toleration. Ed. Ian Shapiro (New Haven: Yale University Press, 2003), 101.

33. Ibid., 102.

34. Ibid., 141.

35. Walter E. Williams. Do the Right Thing (Stanford: Hoover University Press, 1995), vii-viii.

36. Ibid., viii emphasis original.

37. Ibid., viii-ix. 
38. Ibid., ix.

39. Ibid., 40.

40. Ibid., 57-58.

41. Ibid., 71-72.

42. Ibid., 72.

43. For more on neoconservatism, see Douglas Murray's, Neoconservatism: Why We Need It (New York: Encounter Books, 2006), and Irving Kristol's, Neoconservatism: The Autobiography of an Idea (New York: The Free Press, 1995).

44. Leo Strauss. Natural Right and History. $7^{\text {th }}$ ed. (Chicago: University of Chicago Press, 1970), 2.

45. Ibid., 13 .

46. Ibid., 13-14.

47. Francis Fukuyama, America at the Crossroads: Democracy, Power, and the Neoconservative Legacy (New Haven: Yale University Press, 2007), 48.

48. Allan Bloom. The Closing of the American Mind (New York: Simon \& Schuster, 1987), 330.

49. Ibid., 153.

50. Alan Keyes, "The Message of Freedom," in Our Character, Our Future. Ed. George Grant (Grand Rapids: Zondervan Publishing House, 1996), 13.

51. Ibid., 10.

52. Alan Keyes, "The Crisis of Character," in Our Character, Our Future. Ed. George Grant (Grand Rapids: Zondervan Publishing House, 1996), 15. 
53. Ibid., 16.

54. Ibid., 20-21.

55. Alan Keyes, “The Human Conscience and Justice," in Our Character, Our Future. Ed. George Grant (Grand Rapids: Zondervan Publishing House, 1996), 113.

56. Ibid., 114-115.

57. Ibid., 115.

58. Ibid., 116.

59. Ibid., 115. 


\section{Bibliography}

Edmund Burke, "Reflections on the Revolution in France," in The Portable Edmund Burke. Ed. Isaac Kramnick (New York: Penguin Books, 1999).

Joseph Conti, Stan Faryna, Brad Stetson, Black and Right: The Bold New Voice of Black Conservatism in America (Westport, Connecticut: Praeger, 1997).

Joseph Conti, Brad Stetson, Challenging the Civil Rights Establishment: Profiles of a New Black Vanguard (Westport, Connecticut: Praeger, 1993).

Francis Fukuyama, America at the Crossroads: Democracy, Power, and the Neoconservative Legacy (New Haven: Yale University Press, 2007).

F. A. Hayek, Law, Legislation and Liberty. 3 vols. (Chicago: The University of Chicago Press, 1973-1979).

David Hume, Enquiries Concerning the Principles of the Understanding and the Principles of Morality. $3^{\text {rd }}$ ed. Ed. P.H. Nidditch (Oxford: Oxford University Press, 1990).

Alan Keyes, "The Message of Freedom," in Our Character, Our Future. Ed. George Grant (Grand Rapids: Zondervan Publishing House, 1996).

Alan Keyes, "The Crisis of Character," in Our Character, Our Future. Ed. George Grant (Grand Rapids: Zondervan Publishing House, 1996).

Alan Keyes, "The Human Conscience and Justice," in Our Character, Our Future. Ed. George Grant (Grand Rapids: Zondervan Publishing House, 1996).

Irving Kristol, Neoconservatism: The Autobiography of an Idea (New York: The Free Press, 1995).

John Locke, Two Treatises of Government and A Letter Concerning Toleration. Ed. Ian Shapiro (New Haven: Yale University Press, 2003).

Jerry Z. Muller, Conservatism: An Anthology of Social and Political Thought from David Hume to the Present (Princeton: Princeton University Press, 1997).

Douglas Murray, Neoconservatism: Why We Need It (New York: Encounter Books, 2006).

Michael Oakeshott, Rationalism In Politics and Other Essays (Indianapolis: Liberty Fund, 1962). 
George S. Schuyler, Black and Conservative: The Autobiography of George S. Schuyler (New Rochelle: Arlington House Publishers, 1966).

George S. Schuyler, "The Future of the American Negro," in Rac[e]ing To the Right. Ed. Jeffrey B. Leak (Knoxville: University of Tennessee Press, 2001).

Thomas Sowell, Knowledge and Decisions. (New York: Basic Books, 1996).

Thomas Sowell, The Vision of the Anointed: Self-Congratulation as a Basis for Social Policy. (New York: Basic Books, 1995).

Thomas Sowell, A Personal Odyssey (New York: Simon \& Schuster, 2000).

Thomas Sowell, A Man of Letters (New York: Encounter Books, 2007).

Leo Strauss, Natural Right and History. $7^{\text {th }}$ ed. (Chicago: University of Chicago Press, 1970).

Eric Voeglin, The New Science of Politics (Chicago: The University of Chicago Press, 1997).

Walter E. Williams, Do the Right Thing (Stanford: Hoover University Press, 1995). 


\section{E-LOGOS}

\section{ELECTRONIC JOURNAL FOR PHILOSOPHY}

Ročník/Year: 2010 (vychází průběžně/ published continuously)

Místo vydání/Place of edition: Praha

ISSN 1211-0442

Vydává/Publisher:

Vysoká škola ekonomická v Praze / University of Economics, Prague

nám. W. Churchilla 4

Czech Republic

13067 Praha 3

IČ: 61384399

Web: http://e-logos.vse.cz

Redakce a technické informace/Editorial staff and technical information:

Miroslav Vacura

vacuram@vse.cz

Redakční rada/Board of editors:

Ladislav Benyovszky (FHS UK Praha, Czech Republic)

Ivan Blecha (FF UP Olomouc, Czech Republic)

Martin Hemelík (VŠP Jihlava, Czech Republic)

Angelo Marocco (Pontifical Athenaeum Regina Apostolorum, Rome, Italy)

Jozef Kelemen (FPF SU Opava, Czech Republic)

Daniel Kroupa (ZU Plzeň, Czech Republic)

Vladimír Kvasnička (FIIT STU Bratislava, Slovak Republic)

Jaroslav Novotný (FHS UK Praha, Czech Republic)

Jakub Novotný (VŠP Jihlava, Czech Republic)

Ján Pavlík (editor-in-chief) (VŠE Praha, Czech Republic)

Karel Pstružina (VŠE Praha, Czech Republic)

Miroslav Vacura (executive editor) (VŠ́E Praha, Czech Republic) 